\title{
Social Media Customer Expectations: Brand Engagement in Maintaining Customer Loyalty
}

\author{
L.A. Wibowo, Lisnawati, R. Adzimaturrahmah \\ Universitas Pendidikan Indonesia, Indonesia \\ Email: rozana@student.upi.edu
}

\begin{abstract}
This study aimed to find out the description of the level of brand engagement and customer loyalty on Twitter social media users in Indonesia. The research design of this study was a cross-sectional method. This study used a descriptive approach and explanatory survey method. A total of 106 respondents were selected by simple random sampling. A questionnaire was used as a research instrument to collect data from respondents. The analysis technique was a descriptive technique by using frequency distribution. Furthermore, the data were calculated using path analysis to gain understanding the relationship between variables. The result of this study showed that brand engagement is in good enough categories, while customer loyalty is in good enough category. The differences in this study located on object research, time research, measuring instruments, literature used, the theory used and the results of the study.
\end{abstract}

Keywords: brand engagement, customer loyalty, social media

\section{INTRODUCTION}

The advancement in science and technology, especially the internet, has changed the way people communicate, from initially one-to-many to many-to-many. One-tomany communication became many-to-many developing in the new media era (Alexander \& Jaakkola, 2015). New media is a broader term in media studies that emerged in the latter part of the $20^{\text {th }}$ century which refers to requests for access to content anytime, anywhere, on digital devices, as well as interactive user feedback, creative participation, and community-building around media content. One of the phenomena of new media is the growth of social media (F. Breidbach, Brodie, \& Hollebeek, 2014). This condition is a business opportunity for existing companies, to continue to exist among companies engaged in the same field, all companies must be able to provide satisfaction for each of their customers (Kipkirong Tarus \& Rabach, 2013). The condition of a company's success in competition is trying to create and retain customers (Wang \& Feng, 2012). This is because most of the company's revenue is obtained from repurchases by consumers (Brodie, Ilic, Juric, \& Hollebeek, 2013). Indonesia is a developing country which is in the fourth rank as the country with the most population in the world.

The growth of internet users in Indonesia is increasing along with the rapid growth of information technology. Many netizens use the internet for a variety of reasons, from work to personal matters. The data from the Indonesian Internet Service Providers Association (APJII) in 2017 indicated that the number of internet 
users in Indonesia reached 143.26 million. That number increased compared to the previous year, in 2016 which reached 132.7 million people.

The APJII survey revealed that internet penetration in Indonesia in 2017 was 143.26 million people (54.68\%) of the total Indonesian population of 262 million. This number has increased significantly compared to 2016 where internet user penetration in Indonesia was 132.7 million (52.5\%). The growth of internet users in Indonesia will continue to increase yearly. The internet is currently in a phase of rapid growth, driven from the demand side in line with the growth of the wealth of the new middle class, meaning that without growth it is believed internet shopping is also hampered. Internet users are individuals who access the internet either from personal computer devices, personal mobile devices, both or from other facilities.

The online market of the first twenty centuries, together brought a fundamental change to consumers' lifestyles, forcing organizations to change the way they do business (Bowen \& Chen McCain, 2015). Certain circumstances increase consumer demand for superior services, together with the acceptance and widespread use of information technology, mobile devices, the internet, and social media require companies to rethink their business environment, utilize technological developments such as social media gives benefit for companies to obtain expected results (Ennew \& Devlin, 1993).

One of the fast-growing social media is Twitter, Twitter is one of the second largest social media in the world after Facebook, seen from the number of users (Mainela \& Ulkuniemi, 2013). This social media has certain peculiarities that distinguish it from other social medias, known as posting 140 characters (Sashi, 2012). Since its inception, Twitter has experienced rapid growth and is quickly gaining popularity worldwide, until January 2013 there were more than 500 million registered users on Twitter, 200 million of them are active users, not only popular abroad, in Indonesia Twitter also experienced quite rapid development, this happened because Indonesia is one of the countries with high numbers of internet users (Bitter, Kräuter, \& Breitenecker, 2014).

The research on customer loyalty conducted at Airline and banking shows that with a very sharp competition, the model of customer satisfaction is considered inappropriate (Kandampully, Zhang, \& Bilgihan, 2015). This paradigm was also very popular in marketing and strategic thinking in America until the mid-1980s (Zaki, Kandeil, Neely, \& McColl-Kennedy, 2016).

The idea is that satisfied consumers are loyal, and loyal consumers will benefit (Yavas et al., 2014), so that to satisfy consumers, companies emphasize service quality and at the same time satisfy consumers (Wirtz et al., 2013). Since the early 1990s and specifically 1994, several studies have been the paradigm of consumer satisfaction. Researchers then tried to develop methods to measure the financial effects of quality improvement measures (Watson, Beck, Henderson, \& Palmatier, 2015). Many companies in the late 1980s and early 1990s received quality prizes but were very bad in their financial aspects (Wu \& Tseng, 2014).

Satisfied consumers do not always guarantee loyalty, even for certain industries up to $75 \%$ of customers who move to other companies say they are satisfied with the previous company. Customers can move to other companies because of price, competitors offer new opportunities and also sometimes they need variation (Yavas et al., 2014). Customer loyalty is one of the important keys of the 
company in winning the market with fierce business competition because in competition the company will maintain its continuity, by retaining customers (Yavas et al., 2014).

The development of social media in the world makes it easy for companies that have the brand to be well known to many people, one of which has been explained earlier is Twitter. Twitter is experiencing rapid growth every year, Twitter has become a marketing tool in business, a casual medium for communication, even a campaign tool in politics. The formed of Twitter in 2006 until now has been much in demand by people in the world, but not a few problems experienced by Twitter, twitter user has been decreased because of the loss of competition with other social media (tekno.kompas.com). The data from Statista.com showed that active social media users in 2015 were Facebook at 30.3 million, Snapchat at 8.5 million, YouTube at 8.0 million, Instagram at 7.1 million, Pinterest at 4.0 million and Twitter at 2.7 million. It can be seen in 2015 Twitter has decreased which affects the number of existing Twitter users. The number of social media that releases new features is more interesting than Twitter, like Facebook, Instagram, Snapchat and many others.

Many factors make Twitter lose to this competition; one of the reasons is the development of Twitter users which is increasingly receding. Since 2015-2016 Twitter lost many users because it switched to Instagram and Snapchat which have similar features even more than Twitter. An example is Hashtag, although Twitter was the first to launch Hashtag now all social media platforms use Hashtag as one of its features.

Loyalty is proof that consumers are always consumers, who have the strength and positive attitude towards the company. Consumer loyalty to a particular brand of goods or services depends on several factors, the amount of the cost to move to another brand of goods or services, the similarity in quality, quality or service of the type of substitute goods or services, the risk of changing costs due to the replacement goods or services and changes in the level of satisfaction gained from new brands compared to experience with previous brands that have been used (Kang, Alejandro, \& Groza, 2015). Companies that provide a good image for consumers, it is more likely for consumers to make repeat purchases, which in return it can make consumers loyal (Watson et al., 2015).

Customer loyalty is a behavioral impulse to make repeated purchases and to build customer loyalty to a product or service produced by the business entity takes a long time to go through an iterative buying process (Rezghi Rostami, Valmohammadi, \& Yousefpoor, 2014). The value of company customer loyalty is loyalty that influences large trades such as positive word of mouth and is more resistant to competition that means loyal customers (Ennew \& Devlin, 1993).

The approach or grand theory used to overcome the problems of customer loyalty in this study is the theory of customer behavior from (Kotler \& Keller, 2012), consumer behavior is the study of how individuals, groups, and organizations choose, buy, use, and dispose of goods, services, ideas, or experiences to meet their needs and desires. Marketers must fully understand the theory and reality of consumers. Consumer purchasing behavior is influenced by cultural, social, and personal factors; from these factors, culture provides the widest influence to influence consumer behavior. 
Customer loyalty can be created because the customer is satisfied with the product, it can be in the form of goods or services that he bought (Kabadayi \& Price, 2014). Loyal customers are more valuable in short and in the long term, they think of future business. Based on the measurements used by customers, it can be measured in three aspects of attitudes, behavior and general aspects (Zaki et al., 2016). Customer loyalty based on factors that occur some affect, the first is the trust which mean customer must trust a product, the second relationship that should be greater positive value, third can create a positive emotional level (Bricci, Fragata, \& Antunes, 2016).

The benefits of customer loyalty, help relationships between customers and companies that are mutually beneficial (Chen \& Wang, 2016). Loyal customers show commitment and strong evidence towards the company and are not interested in competing companies (Kandampully et al., 2015). Furthermore, loyal customers who are willing to pay more express higher purchase intentions and resist switching. It is important for companies to have loyal customers (Sajtos, Kreis, \& Brodie, 2015). Customer Loyalty presents a deep commitment to customers to consistently repurchase certain brands. Brand involvement enhances brand experience and fosters brand trust and brand loyalty (Brodie et al., 2013).

The company is very involved in giving a good brand image and is involved in its application. Brand engagement as a factor that must be possessed by digital technology or social media application, is a concept that has not yet fully developed in marketing. Initially, the concept of brand engagement is in the field of psychology known as employee engagement (Vivek, Beatty, \& Morgan, 2012). The implementation of employee engagement concept into brand engagement was previously proposed (D. Kaltcheva, Patino, V. Laric, A. Pitta, \& Imparato, 2014). Both of these concepts have the same characteristics that reflect feelings of passion (Sarkar \& Sreejesh, 2014).

Twitter engages as a solution to the problems experienced by customers regarding how much customer brand involvement and customers to the brand. An intense engagement relationship between the customer and the brand can affect customer satisfaction, based on the level of relationship and emotional interaction that is felt by the customer (Sashi, 2012). The satisfaction is in the form of affective responses such as pleasure when customers use company services (Gummerus, Liljander, Weman, \& Pihlström, 2012). The engagement process takes place, the customer tries to increase knowledge and social interaction with the company brand or other customers to find out more information about the company's brand (Wirtz et al., 2013).

The existence of an engagement relationship between customers and companies can be an alternative evaluation for customers to assess how the services provided by the company feel satisfied or not (Brodie et al., 2013). Based on the background of the research that has been described to find out whether brand engagement conducted on social media twitter in Indonesia is successful or not, then researchers to conduct research entitled "The Effect of Brand Engagement on Customer Loyalty" (Survey on Twitter social media users in Indonesia).

Based on the background, the following research problems can be formulated: 1) How is the description of brand engagement on Twitter social media users in Indonesia; 2) How is the description of customer loyalty on Twitter social media 
users in Indonesia; and 3) How is the influence of brand engagement on customer loyalty simultaneously and partially. Based on the problem formulation above, the purpose of this study is to obtain findings regarding: 1) The description of brand engagement on Twitter social media users in Indonesia; 2) The description of customer loyalty on Twitter social media users in Indonesia; and 3) The influence of brand engagement on customer loyalty simultaneously and partially.

\section{METHODS}

Based on the level of explanation and the field of research, this type of research was descriptive and verification research. Descriptive research is a type of conclusive research that has the main purpose description of something (Dutot, 2013). This descriptive study aimed to describe, give a systematic, factual and accurate picture, overcome the facts, and the relationship between the phenomena investigated without connecting other variables or making comparisons. The purpose of this descriptive study was to find out the overall picture of brand engagement and customer loyalty. Verification research or causality research is research to test the truth of causal relationships, namely the relationship between independent variables with the dependent variable (Dutot, 2013), in this study the truth of the hypothesis would be tested through data collection in field, regarding the effect of brand engagement on customer loyalty.

The research method used was an explanatory survey method. The explanatory survey is conducted to explore the problem situation, which is to get ideas and insights into the problems faced by the management or researchers (Malhotra, 2010). The experimental research method is a research method used to look for the effect of certain treatments. The survey method is used to obtain data from a particular place that is natural (not artificial), but research conducts treatment in data collection (Sugiyono, 2019).

The type of data used in this study were primary data and secondary data. The use of primary data aims to obtain a real picture of those who know or have data about this research. Meanwhile, secondary data is primary data or by other parties as in the form of tables or diagrams (Rezghi Rostami et al., 2014). Data collection techniques refer to the way that needs to be done in research to obtain data. Data collection techniques can be done by combination directly or indirectly.

This sampling data technique is usually based on certain considerations, such as limited time, manpower and funds so that it cannot take large and distant samples. The sampling in this study used a simple random sampling technique which is a random sampling technique that provides equal opportunities to the population to be sampled. This study obtained data using the following techniques; Literature study is secondary data collection by studying literature such as books, journals, magazines, websites, and institutional documents relating to the theory or concept of research problems, Questionnaire is data collection techniques through the distribution of a set of written questions to respondents who become research sample.

Testing the validity of the instrument is done to ensure that there is a similarity between the data collected and the data that occurs on the object under study, 
reliability testing shows that each instrument is reliable enough to be used as a data collection tool because the instrument is good and can produce data that can be trusted.

The data analysis technique used to determine the correlative relationship in this study was path analysis technique. To test the hypothesis, where the method of analysis carried out in this quantitative study was the verification method of analysis, and then the path analysis was performed. This analysis was used to determine the magnitude of the influence of dimensions on the brand engagement variable on $\mathrm{Y}$, which is doing repeated purchases and to build customer loyalty to a product or service.

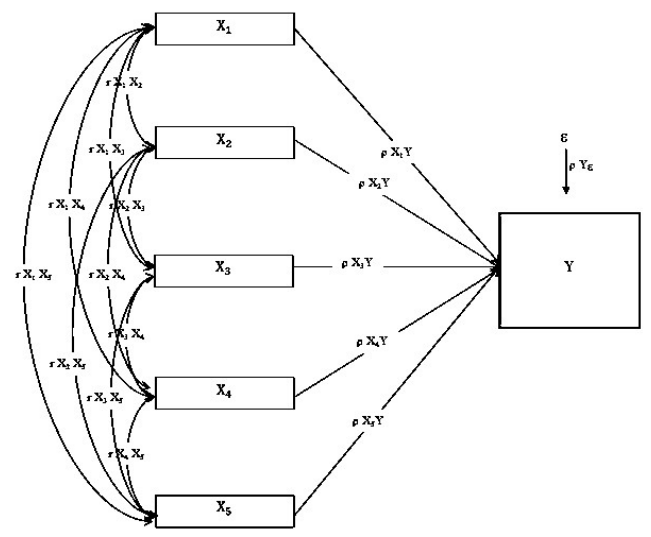

Figure 4. Structure of Causal Relationship between X1, X2, X3, X4, X5, and Y

The path analysis model was used to analyze the pattern of relationships between variables to determine the direct and indirect effects of a set of independent (exogenous) variables on the dependent variable (endogenous).

\section{RESULTS \& DISCUSSION}

A normality test is conducted to determine whether the data obtained from observations are normally distributed or not so that the data can be used or not in the path analysis model. To find out whether the data obtained is normally distributed or not, it can be done with statistical test analysis. The Kolmogorov Smirnov Test is to strengthen the above test results as follows:

Table 1. Kolmogorov Smirnov Test

\begin{tabular}{|c|c|}
\hline & 106 \\
\hline $\begin{array}{l}N \\
\text { Normal Parameters }{ }^{a, b} \text { Mean }\end{array}$ & .0000000 \\
\hline Std. Deviation & 9.54885399 \\
\hline Most Extreme Differences & .085 \\
\hline Positive & .066 \\
\hline Negative & -.085 \\
\hline Test Statistic & .085 \\
\hline Asymp. Sig. (2-tailed) & $.056^{\mathrm{c}}$ \\
\hline $\begin{array}{l}\text { b. Test distribution is Normal. } \\
\text { c. Calculated from data. }\end{array}$ & \\
\hline
\end{tabular}


Based on the results of Table 1, it can be seen that the significance value for the normality of research data was 0.056 . This value $>0.05$ so that the research variable data was stated to have a data distribution with a normal distribution. The hypothesis of this study wass brand engagement towards customer loyalty. This hypothesis was tested simultaneously or partially using SPSS 22.0 for windows.

Table 2. Simultaneous Hypothesis Test (Anova)

\begin{tabular}{lllllll}
\hline Model & & $\begin{array}{l}\text { Sum of } \\
\text { Squares }\end{array}$ & Df 1 & $\begin{array}{l}\text { Mean } \\
\text { Square }\end{array}$ & F & Sig. \\
\hline 1 & Regression & 47545.545 & & 47545.545 & 516.477 & $.000^{\mathrm{b}}$ \\
& $\begin{array}{l}\text { Residual } \\
\text { Total }\end{array}$ & 9573.964 & 104 & 92.057 & & \\
\hline
\end{tabular}

a. Dependent Variable: Customer Loyalty

b. Predictors: (Constant), Brand Engagement

Overall testing results provided significant results. Thus to know each dimension that had a significant effect on customer loyalty could be continued with partial testing. The following Table 3 shows the results of calculations from partial testing:

Table 3. Partial Hypothesis Test

\begin{tabular}{lccccc}
\hline \multirow{2}{*}{ Model } & \multicolumn{2}{c}{$\begin{array}{l}\text { Unstandardized } \\
\text { Coefficients }\end{array}$} & \multicolumn{2}{l}{ Standardized Coefficients } & \\
\cline { 2 - 4 } & $\mathrm{B}$ & Std. Error & Beta & $\mathrm{T}$ & Sig. \\
\hline Consumption & .431 & .227 & .139 & 1.902 & .060 \\
Curation & .573 & .249 & .171 & 2.304 & .023 \\
Creation & .453 & .522 & .102 & .867 & .388 \\
Collaboration & 1.034 & .451 & .233 & 2.296 & .024 \\
Interaction & 2.089 & .595 & .350 & 3.511 & .001 \\
Constant) & 5.049 & & & 2.045 & .043 \\
\hline
\end{tabular}

a. Dependent Variable: Customer Loyalty

From the Table 3, it could be concluded that if the probability value (Sig) of the study $<0.05$. In the results above, it was stated that the dimensions of curation, collaboration and interaction have a significant effect on customer loyalty. The brand engagement variable consisted of 5 indicators: 1) Consumers will not switch brands; 2) Consumers feel lost if the brand does not exist anymore; 3) Consumers always try new products offered by this brand; 4) Consumers will continue to buy these brand products even though there is bad news about this brand; and 5) Consumers feel incomplete if they do not buy or use this brand (Purbasari \& Purnamasari, 2015).

Based on the research results of the questionnaire distributed to 106 respondents, it could be seen that the brand engagement of social media users on Twitter in Indonesia got a score of 7813 or the percentage of $65.81 \%$ of the ideal score of 11872. Based on the dimensions, the dimension that got the highest score was the dimension of curation with a score of 2008 or $25.70 \%$. While the dimension that got the lowest score was the interaction dimension with a score of 945 or $12.09 \%$. Based on indicators, the indicator that got the highest score was filtering information through social media twitter with the acquisition of a score of 530 . 
While the indicator that got the lowest score was the user still actively using Twitter as social media with the acquisition of a score of 440 .

Brand management is a marketing strategy in managing a product, it can also be called the art of brand management. Brands are very important in imaging a quality product (Resa \& Wibowo, 2016). Engagement influences customer loyalty. Good service from the company makes consumers can revisit to the same place even though there are many competitors (Hussein, 2016).

Brand engagement is important because the brand will always be in the minds of customers and the brand provides an experience to customers who have used the brand, and customers will automatically judge whether the brand is good or bad. Whether the customer wants to use it again or not depends on how the customer values the brand according to expectations or not, satisfying or not, if it is yes, the customer will continue to return and remain involved with the same brand if it is not, the customer will leave the old brand and look for a new brand which is better (Vivek et al., 2012).

The customer loyalty variable consists of six indicators: 1) Repurchase; 2) The habit of consuming the brand; 3) Always like the brand; 4) Keep choosing the brand; 5) Having confidence that the brand is the best; and 6) Recommending the brand to other people (Dutot, 2013). Based on the results of research from questionnaires distributed to 106 respondents, it could be seen that customer loyalty of Twitter social media users in Indonesia got a score of 6649 or the percentage of $64.01 \%$ from the ideal score of 10388. Based on dimensions, the dimension that got the highest score was the dimension of customer retention with a score of 2897 or $43.56 \%$. While the dimension that got the lowest score was the dimension of word of mouth with a score of 1837 or $27.62 \%$. Based on indicators, the indicator that got the highest score was the amount of user influence for the company with the acquisition of a score of 502. While the indicator that got the lowest score was the intensity of talking about twitter to close friends with the acquisition of a score of 434 .

Loyalty means being loyal, or loyalty can be interpreted as devotion. Efforts made to create consumer satisfaction are more likely to influence consumer attitudes. The concept of consumer loyalty places more emphasis on buying behaviour (Kang et al., 2015). Customers are people or buyers who do not depend on a product, but products that depend on that person (Love, Staton, \& Rotman, 2016). Customer loyalty as part of human activities that always changes according to environmental and social influences where he is. Consumer behavior that is expected to continuely exist for the company is loyalty. Loyalty means that customers continue to make regular purchases.

The scope of customer behavior includes many things because customer behavior is a study of processes that develop when individuals or groups of people choose, use, or discard a product, service, idea, or experience to satisfy their needs and desires. Customer behavior can be concluded as a study of a person or group in determining their rights in choosing, buying, using, and replacing a product or service (Deniarni \& Lisnawati, 2016). 


\section{CONCLUSION}

Based on the results of empirical research on brand engagement on Twitter social media users in Indonesia, it was found that the consumption dimension did not contribute well enough to twitter social media users in Indonesia to increase customer loyalty. The indirect effect of the consumption dimension on customer loyalty, based on the results of empirical research on brand engagement on Twitter social media users in Indonesia, it was found that the curation dimension contributed quite well to twitter social media users in Indonesia to increase customer loyalty. The curation dimension had a direct effect on customer loyalty. Based on the results of empirical research on brand engagement on Twitter social media users, it was found that the creation dimension had not made a good contribution to Twitter social media users in Indonesia to increase customer loyalty. The dimension of creation had an indirect effect on customer loyalty, based on the results of empirical research on brand engagement on Twitter social media users in Indonesia; it was found that the collaboration dimension had contributed quite well to Twitter social media users in Indonesia to increase customer loyalty. The collaboration dimension had a direct effect on customer loyalty. Based on the results of empirical research on brand engagement on Twitter social media users in Indonesia, it was found that the interaction dimension had contributed quite well to Twitter social media users to increase customer loyalty. The interaction dimension had a direct effect on customer loyalty, based on the above research entitled the influence of brand engagement on customer loyalty had the result that every dimension owned by brand engagement influenced whether or not to the customer loyalty, the results were 2 dimensions that did not affect customer loyalty which were consumption and creation, there were 3 dimensions affected customer loyalty which were curation, collaboration, and interaction.

\section{REFERENCES}

Alexander, M., \& Jaakkola, E. (2015). Customer engagement behaviours and value cocreation.

Bitter, S., Kräuter, S. G., \& Breitenecker, R. J. (2014). Customer engagement behaviour in online social networks-The Facebook perspective. International Journal of Networking and Virtual Organisations, 14(1/2), 197. doi: 10.1504/IJNV0.2014.065088

Bowen, J. T., \& Chen McCain, S.-L. (2015). Transitioning loyalty programs: A commentary on "the relationship between customer loyalty and customer satisfaction". International Journal of Contemporary Hospitality Management, 27(3), 415-430. doi: 10.1108/IJCHM-07-2014-0368

Bricci, L., Fragata, A., \& Antunes, J. (2016). The effects of trust, commitment and satisfaction on customer loyalty in the distribution sector. Journal of Economics, Business and Management, 4(2), 173-177. doi: 10.7763/JOEBM.2016.V4.386 
Brodie, R. J., Ilic, A., Juric, B., \& Hollebeek, L. (2013). Consumer engagement in a virtual brand community: An exploratory analysis. Journal of Business Research, 66(1), 105-114. doi: 10.1016/j.jbusres.2011.07.029

Chen, C.-F., \& Wang, J.-P. (2016). Customer participation, value co-creation and customer loyalty - A case of airline online check-in system. Computers in Human Behavior, 62, 346-352. doi: 10.1016/j.chb.2016.04.010

D. Kaltcheva, V., Patino, A., V. Laric, M., A. Pitta, D., \& Imparato, N. (2014). Customers' relational models as determinants of customer engagement value. Journal of Product \& Brand Management, 23(1), 55-61. doi: 10.1108/JPBM-07-20130353

Deniarni, L., \& Lisnawati, L. (2016). Analisis persepsi virtual brand community terhadap kinerja ekuitas merek disposable diaper merek sweety (survei pada anggota fan page facebook bunda cermat). Journal of Business Management Education (JBME), 1(1), 160-175. doi: 10.17509/jbme.v1i1.2285

Dutot, V. (2013). A new strategy for customer engagement: How do French firms use social crm? International Business Research, 6(9), p54. doi: 10.5539/ibr.v6n9p54

Ennew, C., \& Devlin, J. (1993). Regulating the distribution of savings and investment products: retrospect and prospect. International Journal of Bank Marketing, 11(6), 8-10. doi: 10.1108/EUM0000000001122

F. Breidbach, C., Brodie, R., \& Hollebeek, L. (2014). Beyond virtuality: From engagement platforms to engagement ecosystems. Managing Service Quality: An International Journal, 24(6), 592-611. doi: 10.1108/MSQ-08-2013-0158

Gummerus, J., Liljander, V., Weman, E., \& Pihlström, M. (2012). Customer engagement in a Facebook brand community. Management Research Review, 35(9), 857-877. doi: 10.1108/01409171211256578

Hussein, A. S. (2016). The effect of trust and brand engagement on mobile telecommunication customer loyalty: the mediating effect of brand engagement. Conference Paper. doi: 10.13140/RG.2.2.10734.82245

Kabadayi, S., \& Price, K. (2014). Consumer - brand engagement on Facebook: Liking and commenting behaviors. Journal of Research in Interactive Marketing, 8(3), 203-223. doi: 10.1108/JRIM-12-2013-0081

Kandampully, J., Zhang, T. (Christina), \& Bilgihan, A. (2015). Customer loyalty: A review and future directions with a special focus on the hospitality industry. International Journal of Contemporary Hospitality Management, 27(3), 379414. doi: 10.1108/IJCHM-03-2014-0151

Kang, J., Alejandro, T. B., \& Groza, M. D. (2015). Customer-company identification and the effectiveness of loyalty programs. Journal of Business Research, 68(2), 464-471. doi: 10.1016/j.jbusres.2014.06.002

Kipkirong Tarus, D., \& Rabach, N. (2013). Determinants of customer loyalty in Kenya: Does corporate image play a moderating role? The TQM Journal, 25(5), 473-491. doi: 10.1108/TQM-11-2012-0102

Kotler, P., \& Keller, K. L. (2012). A Framework for Marketing Management. Prentice Hall. 
Love, E., Staton, M., \& Rotman, J. D. (2016). Loyalty as a matter of principle: The influence of standards of judgment on customer loyalty. Marketing Letters, 27(4), 661-674.

Mainela, T., \& Ulkuniemi, P. (2013). Personal interaction and customer relationship management in project business. Journal of Business \& Industrial Marketing, 28(2), 103-110. doi: 10.1108/08858621311295245

Malhotra, N. K. (2010). Marketing research: An applied orientation (6th ed). Upper Saddle River, NJ: Pearson.

Purbasari, D. M., \& Purnamasari, D. L. (2015). Anteseden keterikatan merek dalam membangun hubungan merek pada konsumen (kepercayaan, kepuasan, dan komitmen) terhadap loyalitas. Prosiding Elektronik (e-Proceedings) SNIRT FT UNTAG Cirebon, 5(1).

Resa, A. L., \& Wibowo, L. A. (2016). Kualitas informasi dan keamanan transaksi faktor kunci penunjang perkembangan e-commerce. Strategic: Jurnal Pendidikan Manajemen Bisnis, 16(1), 17-23. doi: 10.17509/strategic.v16i1.4467

Rezghi Rostami, A., Valmohammadi, C., \& Yousefpoor, J. (2014). The relationship between customer satisfaction and customer relationship management system; a case study of Ghavamin Bank. Industrial and Commercial Training, 46(4), 220-227. doi: 10.1108/ICT-10-2013-0067

Sajtos, L., Kreis, H., \& Brodie, R. (2015). Image, brand relationships and customer value: Exploring the moderating role of advertising spending- and labourintensity in customer loyalty. Journal of Service Theory and Practice, 25(1), 51-74. doi: 10.1108/JSTP-11-2013-0261

Sarkar, A., \& Sreejesh, S. (2014). Examination of the roles played by brand love and jealousy in shaping customer engagement. Journal of Product \& Brand Management, 23(1), 24-32. doi: 10.1108/JPBM-05-2013-0315

Sashi, C. M. (2012). Customer engagement, buyer-seller relationships, and social media. Management Decision, 50(2), 253-272. doi: 10.1108/00251741211203551

Sugiyono. (2019). Metode Penelitian Kuantitatif Kualitatif dan R\&D. Alfabeta. Retrieved from /home/catalog/id/151515/slug/metode-penelitiankuantitatif-kualitatif-dan-r-d.html

Vivek, S. D., Beatty, S. E., \& Morgan, R. M. (2012). Customer engagement: exploring customer relationships beyond purchase. Journal of Marketing Theory and Practice, 20(2), 122-146. doi: 10.2753/MTP1069-6679200201

Wang, Y., \& Feng, H. (2012). Customer relationship management capabilities: Measurement, antecedents and consequences. Management Decision, 50(1), 115-129. doi: 10.1108/00251741211194903

Watson, G. F., Beck, J. T., Henderson, C. M., \& Palmatier, R. W. (2015). Building, measuring, and profiting from customer loyalty. Journal of the Academy of Marketing Science, 43(6), 790-825. doi: 10.1007/s11747-015-0439-4

Wirtz, J., den Ambtman, A., Bloemer, J., Horváth, C., Ramaseshan, B., van de Klundert, J., ... Kandampully, J. (2013). Managing brands and customer engagement in online brand communities. Journal of Service Management, 24(3), 223-244. doi: $10.1108 / 09564231311326978$ 
Wu, M.-Y., \& Tseng, L.-H. (2014). Customer Satisfaction and Loyalty in an Online Shop: An Experiential Marketing Perspective. International Journal of Business and Management, 10(1), p104. doi: 10.5539/ijbm.v10n1p104

Yavas, U., Babakus, E., D. Deitz, G., \& Jha, S. (2014). Correlates of customer loyalty to financial institutions: A case study. Journal of Consumer Marketing, 31(3), 218-227. doi: 10.1108/JCM-10-2013-0759

Zaki, M., Kandeil, D., Neely, A., \& McColl-Kennedy, J. R. (2016). The Fallacy of the Net Promoter Score: Customer Loyalty Predictive Model. 26. 